\title{
Repertoar Musik Keroncong dengan Menggunakan Idiom Musik Sunda: Implementasi Model Pembelajaran Kolaborasi pada Mata Kuliah Sejarah Analisis Musik Indonesia di Departemen Pendidikan Musik FPSD UPI Bandung
}

\author{
Hery Supiarza ${ }^{1}$ dan Harry Tjahjodiningrat \\ Prodi Film dan Televisi, FPSD, Universitas Pendidikan Indonesia, Bandung
}

\begin{abstract}
Keroncong Music Repertoire by Using Sundanese Music Idioms: Implementation of Collaborative Learning Models in the History Course of Indonesian Music Analysis at the Department of Music Education of FPSD UPI Bandung. This study discusses the implementation of collaborative learning models in the history course of Indonesian music analysis at the Department of Music Education, UPI Bandung. As a lecturer in this course, the researcher intends to add to the repertoire of keroncong songs, for which since the 1980s, keroncong song production has stalled due to the competition in the Indonesian music industry. The Action Research method was used in this study to develop students' abilities in creating keroncong songs. There were seven (7) stages used in the research, starting from the initial observation, analysis, combining ideas and thought into big themes, evaluation exercises 1, recording and mastering. There are ten keroncong music recordings as the results of this study. They become a repertoire product of student's collaboration by using the Sundanese traditional approach as the basis for creation. Future research will improve the ten products into a more professional recording result. This research can be a reference for applying collaborative learning models to create students' works and creations in arts.
\end{abstract}

Keywords: keroncong music; song repertoire; learning model

\begin{abstract}
ABSTRAK
Penelitian ini mendiskusikan implementasi model pembelajaran kolaborasi pada mata kuliah Sejarah analisis musik Indonesia di Departemen Pendidikan Musik FPSD UPI Bandung. Peneliti sebagai pengampu mata kuliah ini bermaksud untuk menambah repertoar lagu keroncong yang sejak tahun 1980-an produksi lagu keroncong mengalami kemandekan karena persaingan industri musik Indonesia. Metode Action Research digunakan dalam penelitian ini untuk mengembangkan kemampuan mahasiswa dalam menciptakan lagu keroncong. Digunakan 7 tahap, mulai dari observasi awal, analisis, penyatuan ide dan gagasan menjadi tema besar, latihan evaluasi 1, perekaman dan mastering. Hasil penelitian ini tercipta 10 rekaman musik keroncong sebagai produk repertoar yang murni hasil kolaborasi mahasiswa dengan pendekatan tradisi Sunda sebagai dasar penciptaan. Penelitian selanjutnya akan menyempurnakan 10 produk tadi menjadi hasil rekaman yang lebih professional. Penelitian ini dapat menjadi rujukan penerapan model pembelajaran kolaborasi untuk menciptakan karya dan kreasi mahasiswa dalam bidang seni.
\end{abstract}

Kata kunci: musik keroncong; repertoar lagu; model pembelajaran

\section{Pendahuluan}

Musik keroncong merupakan salah satu kekayaan seni yang menjadi representasi sejarah, budaya dan keragaman bangsa Indonesia. Keroncong identik dengan produk seni yang dihasilkan dari kolaborasi ide antara beberapa budaya, sehingga disimpulkan musik keroncong merupakan produk musik hybrid (Ganap, 2000). Sebagai bukti musik keroncong adalah hasil persilangan budaya terkandung pada alat music yang menjadi sumber dari musik keroncong, yakni

Alamat korespondensi: Program Studi Film dan Televisi, FPSD, Universitas Pendidikan Indonesia, Jalan Dr. Setiabudi 229, Bandung, Jawa Barat. E-mail: herysupiarza@upi.edu; HP.: 081321063919. 
dengan adanya alat musik yang bernama cuk dan cak (dalam jenis keroncong Solo) dan Frunga, machina (jenis ke-roncong Tugu). Alat musik ini merupakan transformasi dari ukulele sebagai alat musik pendatang dari Portugis (Supiarza \& Sarbeni, 2021).

Perkembangan musik keroncong telah dimulai sejak abad ke-19 dan mengalami puncaknya awal abad ke-20, tepatnya sekitar tahun 1920-an sampai 1970-an (Suadi, 2017). Sejak tahun 1980an, musik keroncong mengalami kemunduran produksi (Yampolsky, 2013). Kemunduran produksi musik keroncong ini disebabkan karena produksi lagu keroncong mengalami hambatan. Sejak tahun 1980-an sampai sekarang musik keroncong adalah satu jenis musik klangenan, yang dimaksud klangenan adalah repertoar lagu yang ada hanyalah lagu ciptaan masa lalu yang terus direproduksi dalam bentuk aransemen semata (Supiarza \& Sarbeni, 2021). Tidak terdapat lagi produksi lagu keroncong baru.

Berdasarkan alasan tersebut, melalui penelitian ini diharapkan dapat memberikan semangat baru bagi generasi muda terutama dikalangan kampus untuk menambah repertoar lagu keroncong melalui implemetasi model pembelajaran kolaborasi pada mata kuliah analisis musik Indonesia di Departemen Pendidikan Musik FPSD Universitas Pendidikan Indonesia. Peneliti meyakini bahwa hasil penelitian ini memberikan wacana baru bagi perkembangan musik keroncong di Indonesia dengan tawaran repertoar musik keroncong yang diproduksi sebagai hasil implementasi model pembelajaran kolaborasi di mata kuliah Sejarah Analisis Musik Indonesia. Penerapan Model pembelajaran kolaboratif dalam mata kuliah Sejarah Analisis Musik Indonesia dirasa sangat sesuai untuk untuk mencapai tujuan penelitian ini, sebab model pembelajaran kolaboratif adalah filsafat interaksi dan gaya hidup yang menjadikan kerjasama sebagai suatu struktur interaksi yang dirancang sedemikian rupa guna memudahkan usaha kolektif untuk mencapai tujuan bersama (Panitz, 1997).

Tujuan penelitian ini adalah untuk menambah repertoar lagu keroncong yang dirasa mengalami kemunduran sejak tahun 1980-an. Tidak hanya menambah repertoar lagu keroncong, tapi penelitian ini memberikan tawaran satu konsep lagu keroncong yang digali dari akar lagu tradisi Sunda, sehingga peneliti berharap dapat memperkaya jenis baru dalam musik keroncong, yakni keroncong gaya Sunda. Dalam proses penciptaan lagu keroncong dibutuhkan kerjasama tim yang solid, karena musik keroncong adalah jenis musik ensambel yang membutuhkan konstruksi berfikir bersama. Hal ini berkaitan dengan komposisi alat musik yang identik dengan bentuk musik keroncong, yakni adanya alat musik yang bernama: cuk, cak, cello, bas dan alat musik melodi flute atau biolin. Dalam praktiknya penciptaan lagu keroncong sangat berhubungan dengan kemampuan bermain alat musik sebagai bagian yang tak terpisahkan, sehingga kolaborasi antara pemain akan sangat membantu untuk mendapatkan hasil lagu keroncong yang lebih baik.

Dalam penelitian ini musik keroncong ditempatkan sebagai objek kajian, bertitik tolak dari fakta empiris bahwa musik keroncong sebagai ekspresi simbolik. Sebagai objek kajian, musik keroncong ditempatkan dalam perspektif estetik dan sosio-budaya. Pada perspektif estetik, musik keroncong menjadi objek yang dipahami berdasarkan dimensi intraestetik. Pada perspektif sosio-budaya, musik keroncong menjadi objek yang dipahami berdasarkan dimensi ekstraestetik, lihat (Rohidi, 2011). Penelitian ini mengeksplorasi musik keroncong sebagai objek kajian yang didasarkan pada dimensi intraestetik dan ekstraestetik. Analisis dimensi intraestetik dijadikan titik tolak pembanding dalam konteks analisis nilai seni. Dimensi ekstraestetik diarahkan dalam upaya untuk memahami proses pemaknaan seni dalam mengkaji faktor non-estetik. Dalam implementasi model pembelajaran kolaboratif, hal utama yang dapat dipahami oleh mahasiswa sebagai peserta didik adalah nilai estetik sebagai pemaknaan awal sebagai dasar analisis musik keroncong.

\section{Musik Keroncong}

Apa itu musik?, pertanyaan ini penting untuk mencari tahu pengertian musik secara komprehensif. Musik sebagai suara-suara dan kesunyian-kesunyian yang terorganisir (Elliott, 1995: 20). Akan tetapi, pendapat tersebut belum memadai untuk mendefinisikan apa 
itu musik, sanggahan ini diungkapkan oleh Levinson (Elliott, 1995: 20). Pendapat lain mengenai musik, dikatakan Suka Hardjana, yakni:"tentu saja semua akan setuju, suka atau tidak suka, bila dikatakan lagu "Bengawan Solo" itu musik". Akan tetapi selangkah kita munculkan lagi pertanyaan, mengapa karya Gesang itu disebut musik? (Hardjana, 2003: 4). Tentu tidak mudah menjawabnya. Ada syaratsyarat yang harus dipenuhi sehingga kita bisa menyebutnya musik, syarat-syarat ini sangat mendasar dan harus dipenuhi dalam berbagai rekayasa komposisi bunyi, syarat itu terkandung dalam "Bengawan Solo" seperti: bentuk (form), Kerangka dasar (struktur), nada-nada (kepastian tinggi-rendahnya suara atau sound pitch yang selalu dapat diulang dan dipindah suarakan (transposisi) dalam ketepatan yang sama, ritme (irama), melodi (lagu), dan suasana dan watak bunyi (tone color). Dari penjelasan tersebut di atas, keroncong adalah musik, karena prasyaratprasyarat musik ada dan lengkap di dalam keroncong, maka inilah suatu jenis musik lain dari berbagai macam jenis musik, yaitu: musik keroncong.

Terciptanya jenis musik keroncong, tidak dapat dipisahkan dari keberadaan bangsa Barat (Portugis dan Belanda) di Indonesia. Dikatakan oleh Victor Ganap: "musik keroncong berasal dari musik Portugis abad ke-16 yang disebut fado, berasal dari istilah Latin berarti 'nasib' (Ganap, 2006: 2). Akan tetapi dalam perkembangannya, Belanda memiliki peran yang sangat penting atas keberadaan musik keroncong dan perkembangan musik hubungannya dengan silang budaya. Meski akarnya bukan dari Belanda dan bukan pula Indonesia, di bumi Indonesia di bawah kekuasaan Belandalah keroncong mengkompromikan wilayah tengah antara estetika Eropa dan Asia dan praktikpraktik sosial (Barendregt, Bart. Bogaerts, 2016). Berdasarkan berbagai konsep musik keroncong yang berkembang, dapat dikenali gaya-gaya permainan yang berdasarkan pada pluralisme repertoar musik keroncong. Ada beberapa pendapat mengenai repertoar musik keroncong ini (Margaret J. Kartomi, David Goldsworthy,
Catherine Falk, 1978: 146) membagi menjadi empat jenis, yaitu: (1) keroncong asli, (2) stambul, (3) langgam keroncong, dan (4) langgam Jawa dan keroncong beat. Sementara (Yampolsky, 2013: 266) membagi menjadi (1) keroncong asli, (2) stambul, (3) langgam, dan (4) langgam Jawa. Sedangkan (Harmunah, 1996: 17) membagi menjadi empat bagian, yaitu: (1) keroncong asli, (2) stambul, (3) langgam, dan (4) keroncong ekstra. Pembagian berdasarkan periodesasi keroncong dikemukakan oleh (Lisbijanto, 2013: 13) membagi menjadi: (1) masa keroncong tempo doeloe (1880-1920), (2) masa keroncong abadi (1920-1959), (3) masa keroncong modern (1959-2000), dan (4) keroncong milenium (2000-sekarang). Repertoar keroncong yang dikemukan di atas menjadi pakem atau pegangan bagi pemain dan penggemar hingga saat ini.

Setiap orkes keroncong wajib memahami pakem tersebut, termasuk mahasiswa mata kuliah sejarah analisis musik Indonesia di Departemen Pendidikan Musik FPSD UPI. Diharapkan setiap mahasiswa yang menjadi peserta mata kuliah ini paham betul dengan pakem keroncong. Sebab, diawal terbentuknya suatu kelompok keroncong selalu dimulai dengan berlatih dengan salah satu genre yang menjadi pakem. Biasanya mereka memulai dengan langgam keroncong, hal ini disebabkan banyak judul lagu langgam keroncong yang popular di telinga para anak muda, selain itu bentuk kerangka harmoninya seperti lagu-lagu pop yang sehari-hari sangat lekat dengan anak muda (Supiarza \& Sarbeni, 2021).

\section{Repertoar Musik Keroncong}

Repertoar berasal dari bahasa Perancis yaitu repertoire. Menurut Latifah: "repertoar merupakan bekalan komposisi yang ada pada seorang seniman penyelenggara pagelaran musik" (Latifah, 1983: 62). Repertoar memiliki pengertian kumpulan lagu-lagu (Joan, 1989: 134). Menurut Suharto: "repertoar berarti sejumlah komposisi yang harus disiapkan untuk sebuah acara atau program tertentu" (Suharto, 1982: 114). Dalam konteks penelitian ini, 
merujuk kutipan di atas disimpulkan repertoar keroncong merupakan kumpulan lagu-lagu keroncong sebagai bekalan dalam pertunjukan, latihan, lomba dan sebagainya. Repertoar musik keroncong telah mengalami kemunduran produksi lagu keroncong sejak tahun 1980-an, yang ditunjukkan pada tabel 1 .

Berdasarkan tabel tersebut terbukti di tahun 1980-an sampai hari ini keroncong mengalami kemunduran dalam produksi lagu, bahkan tidak terdengar sama sekali ada lagu baru yang diproduksi. Adapun pertunjukan atau rekaman keroncong masa kini hanyalah pengulanganpengulangan repertoar lagu keroncong sebelum tahun 1980-an, dan hanya semacam klangenan seakan representasi ketidak berdayaan musik keroncong bersaing dengan musik jenis lainnya di kancah industri musik (Supiarza, 2019). Oleh karena itu, penelitian ini berupaya untuk mencari formulasi yang tepat dalam menambah repertoar lagu keroncong, yakni melalui ide dan gagasan mahasiswa generasi masa kini yang tahu dan mengerti bentuk keroncong yang dapat diterima oleh kalangan generasi muda Indonesia, sebab mereka adalah pelakunya.

\section{Model Pembelajaran Kolaboratif}

Mengajar tidak lagi dipahami sebagai proses menyampaikan ilmu pengetahuan dari dosen ke mahasiswa sebagai peserta didik, melainkan lebih sebagai tugas mengatur aktivitas-aktivitas dan lingkungan yang bersifat kompleks dari peserta didik dalam usahanya mencapai tujuan pembelajaran. Penerapan pembelajaran yang berpusat pada dosen, dimana peserta didik terbiasa menerima ilmu pengetahuan secara instan, menjadikannya kurang aktif dalam menggali ilmu pengetahuan dari berbagai sumber belajar. Sehingga untuk menyiasati perlu membuat strategi pembelajaran yang disesuaikan dengan materi pembelajaran dan kemampuan

Tabel 1: Kemunduran produksi lagu keroncong. (Sumber: Supiarza, 2019)

\begin{tabular}{ccccc}
\hline Periode & $\begin{array}{c}\text { Keroncong } \\
(\mathbf{K r})\end{array}$ & $\begin{array}{c}\text { Langgam } \\
(\mathbf{L g m})\end{array}$ & $\begin{array}{c}\text { Stambul } \\
(\mathbf{S t b})\end{array}$ & Jumlah \\
\hline 1920 s.d. 1942 & 1424 & - & 226 & 1650 \\
1950 s.d. 1970 & 157 & 95 & 15 & 267 \\
1980 s.d. sekarang & - & - & - & - \\
\hline
\end{tabular}

dasar peserta didik/siswa. Strategi pembelajaran yang tepat akan membina mahasiswa untuk berpikir mandiri dan menumbuhkan daya kreativitas, dan sekaligus adaptif terhadap berbagai situasi. Hasil kegiatan pembelajaran harus mampu mengembangkan diri mahasiswa sebagai individu yang utuh, sebagai anggota masyarakat, sabagai warga bangsanya (Suryani, 2010). Berkenaan dengan model pembelajaran kolaboratif dari berbagai macam teori dapat disimpulkan bahwa: suatu filsafat pengajaran, bukan serangkaian teknik untuk mengurangi tugas dosen dan mengalihkan tugas-tugasnya kepada para mahasiswa (Suryani, 2010).

Minat belajar mahasiswa masa kini sangat dipengaruhi oleh perubahan dan perkembangan yang tengah berlangsung, oleh karena itu berbagai model pembelajaran harus terus diuji cobakan untuk menemukan suatu formulasi yang paling tepat terhadap perubahan tersebut. Inti pembelajaran kolaboratif adalah bahwa para mahasiswa belajar dalam kelompok-kelompok kecil. Antar anggota kelompok saling belajar dan membelajarkan untuk mencapai tujuan bersama. Keberhasilan kelompok adalah keberhasilan individu dan demikian pula sebaliknya. Kerja kolaborasi adalah suatu proses kerjasama yang dilakukan oleh baik antar individu maupun antar kelompok, yang saling penuh perhatian dan penghargaan sesama anggota untuk mencapai tujuan bersama (penulis) pembelajaran kolaborasi diartikan sebagai berikut:

"Collaborative learning is an educational approach to teaching and learning that involves groups of students working together to solve a problem, complete a task, or create a product" (Gerlach, 1994).

Tinzmann memberikan batasan tentang pembelajaran kolaborasi sebagai berikut:

"Collaborative learning affords students enormous advantages not available from more traditional instruction because a groupwhether it be the whole class or a learning group within the class-can accomplish meaningful learning and solve problems better than any individual can alone" (Tinzmann et al., 1990). 
Berdasarkan batasan ini, pembelajaran kolaborasi menekankan pentingnya pengembangan belajar secara bermakna dan pemecahan masalah secara intelektual serta pengembangan aspek sosial. Oleh karena itu peneliti merasa yakin bahwa model pembelajaran kolaboratif mampu memberikan hasil yang baik pada penelitian ini. Selain itu, sebagai argumentasi yang menjadi landasan peneliti mengimplementasikan model pembelajaran kolaboratif adalah karena musik keroncong merupakan jenis musik ensambel yang memiliki syarat utama kerja tim.

\section{Metode Penelitian}

Metode kualitatif dengan model action research yang digunakan dalam penelitian ini, lebih tepatnya peneliti menggunakan salah satu nama lain dari model action research yakni: partisipatory action research agar terasa lebih tepat karena keterlibatan langsung peneliti. Richard Winter (dalam O'Brien, 1998) memberikan enam ringkasan komprehensif dari prinsip-prinsip utama action research yaitu: (1) reflexive critique, (2) dialectical critique, (3) collaborative resource, (4) risk, (5) pluralstructure, dan (6) theory, practice, transformation. Dalam konteks penelitian ini, peneliti lebih menekankan pada prinsip poin (3) di mana partisipan dalam proyek actions research merupakan anggota peneliti. Prinsip kolaborasi sumberdaya menganggap bahwa tiap ide individu merupakan sumberdaya yang samasama signifikan dalam membuat pengelompokan pemaknaan analisis, yang dinegosiasikan di antara para partisipan (Hasan, 2009). Secara kongkrit tahapan yang dilakukan dalam penelitian ini adalah sebagai berikut:

a. Tahap 1: Observasi dan analisis di lapangan, dalam hal ini di ruang perkuliahan untuk menstimulus ide dan gagasan secara kolaboratif berkenaan topik music keroncong.

b. Tahap 2: Hasil ide dan gagasan disimpulkan dalam bentuk perencanaan yang dihasilkan dari kesepakatan bersama hasil analisis keberagaman teori dan tafsir mengenai musik keroncong dihubungkan dengan musik tradisi Sunda sebagai bahan kolaborasi musikal.

c. Tahap 3: Implementasi dilakukan dengan menciptakan kelompok-kelompok kecil berjumlah 5 orang, jumlah ini berdasarkan syarat dasar dalam bermain ensambel musik keroncong dengan tugas utama bagi setiap orang memilih sebagai pemain cuk, cak, cello, bas dan satu penyanyi.

d. Tahap 4: Setiap kelompok disepakati untuk diberikan kemerdekaan menciptakan nama kelompoknya dan materi lagu yang akan diciptakan berdasarkan lokalitas musik tradisi Sunda.

e. Tahap 5: Diskusi dan uji coba pertama, masingmasing kelompok mempresentasikan serta memainkan lagu keroncong ciptaannya dalam format mentah, artinya masih berupa kerangka ciptaan, Lagu bias bersifat melodi utama tanpa iringan atau diiringi oleh satu atau dua alat musik.

f. Tahap 6: Evaluasi pertama dilakukan perbaikanperbaikan berdasarkan masukan dari kelompok lain dan hasil perbaikan ini dijadikan karya lagu keroncong yang utuh. Sebab hasil tahap ini dapat diketahui kelemahan dan kelebihan dari konstruksi ide-ide setiap kelompok.

g. Tahap 7: Finalisasi, setiap kelompok merekam dalam bentuk audio visual dan hasilnya ditayangkan di channel youtube yang telah disediakan berdasarkan kesepakatan.

h. Tahap 8: Peluncuran repertoar lagu keroncong hasil implementasi pembelajaran kolaboratif dalam bentuk video klip di media sosial.

\section{Hasil dan Pembahasan}

Kolaborasi merupakan suatu metode yang paling tepat dilakukan ketika mata kuliah tersebut memiliki tujuan untuk menciptakan suatu produk, dalam hal ini produk seni (Suryati, Widodo, W, 2020). Dengan kolaborasi dimungkinkan mahasiswa dapat mengkonstruksi ide individual menjadi ide kelompok sehingga dapat diwujudkan menjadi karya kolektif dan secara teknis lebih mudah dilakukan.

Penelitian ini telah dilakukan di awal semester genap, yakni sekitar bulan Maret 2020. Melalui observasi awal dihasilkan analisis yang diimplementasikan dalam bentuk perencanaan untuk 
tahapan selanjutnya (Suryati, Widodo, W, 2020). Tahapan selanjutnya adalah melakukan diskusi kelas untuk merancang dan menyepakati program yang harus dilakukan pada mata kuliah sejarah analisis musik Indonesia untuk menciptakan karya musik keroncong. Bersamaan denga ini pula dikumpulkan berbagai ide dan gagasan mahasiswa merujuk kesepakatan bersama yakni melalui pendekatan music tradisi Sunda sebagai dasar utama penciptaan musik keroncong. Hasilnya pada awal penelitian ini ditentukan perencanaan untuk membuat kelompok kecil, peminjaman alat musik keroncong, pembagian tugas dalam kelompok, evaluasi 1 , perekaman dan mastering.

Observasi merupakan suatu proses pengamatan yang dilakukan oleh kami awal pertemuan, selama dua kali pertemuan, peneliti sekaligus sebagai dosen pengampu dalam mata kuliah Sejarah Analisis Musik Nusantara menerangkan berdasarkan silabus inti sari perkuliahan, tujuan, media dan jenis musik yang digunakan untuk mencapai tujuan akhir perkuliahan yakni sebuah produk musik. Hasil dari observasi ini kemudian diaplikasikan dalam perencanaan mendalam kemudian dibuat kelompok-kelompok kecil berjumlah 6 sampai 7 orang berdasarkan format musik keroncong yang terdiri dari cuk, cak, cello, bas, gitar satu pemain alat musik melodi dan penyanyi. Setelah terbentuk kelompok musik keroncong berikutnya dipilih topik yakni penciptaan lagu keroncong dengan unsur musik tradisi Sunda sebagai elemen utama.

Dari proses penelitian tersebut telah dihasilkan repertoar musik keroncong baru hasil kolaborasi mahasiswa melalui kelompok kelompok kecil, melalui proses latihan kemudian perekaman dan terakhir mastering penelitian ini telah menghasilkan karya musik keroncong berdasarkan musik tradisi Sunda sebanyak 8 karya, karya tersebut seperti berikut:

1. Sangkuriang, Mp3 (90)

https://drive.google.com/file/d/1DlQfiGs Emo23gD1UI1fM3ISa_wuSOM08/view? usp $=$ sharing

2. Sono, Video (90)

https://drive.google.com/file/d/1Fg_WUe EYtBIvhMaHkr9SYODTSF008IRu/view? usp=sharing
3. Kasamat Hate, (80)

https://drive.google.com/file/d/1U0brdm VkOiNLYZRjVNxZpbegDF7Rut46/view? usp=sharing

4. Jawara keroncong Sunda, Mp3 (70) https://drive.google.com/file/d/13b0CyYsJxYL 15iYNMd1cavsx956PoOZA/view? usp=sharing

5. Serba Salah, Mp3 (70) https://drive.google.com/file/d/1WJtok8eBp1O __8TLXzgFrJHhRUpQix6P/view? usp=sharing 6. Ngantosan, Mp3 (83) https://drive.google.com/file/d/12KzUTU gLSgrQ_oisLFj3GnD3XRJfGxRn/view? usp=sharing

7. Ngudak Kahayang, MIDI File (60) https://drive.google.com/file/d/1YzicXbGvWO blp0Xluu_1uBRi22bBrCie/view?usp=sharing

8. Subaya Cinta (format Choir), Mp3 (90) https://drive.google.com/file/d/1xd4SKdYXxxG NvqpxRNPxsP0Pi3MuraHF/view?usp=sharing Dari 8 karya musik keroncong yang telah dihasilkan, tidak semua dari ke 8 karya tersebut berhasil melalui proses perancangan seperti yang telah kami tetapkan. Hal ini terjadi karena dalam prosesnya tiba-tiba muncul pandemi corona yang kemudian menghambat pertemuan atau kolaborasi mahasiswa. Akan tetapi dengan dihasilkannya 8 karya ini, peneliti dapat melihat bahwa implementasi pembelajaran kolaborasi dalam mata kuliah sejarah analisis musik Indonesia, telah berhasil menciptakan repertoar musik keroncong dengan sentuhan anak muda dimana ide penciptaanya mengambil unsur musik tradisi Sunda. Selanjutnya dari 8 karya ini, kami ambil 3 karya terbaik untuk ditindak lanjuti dengan proses perekaman dan mastering semi professional, sehingga dapat menjadi bahan yang menjadi contoh sebuah proses pembelajaran kolaborasi bagi angkatan selanjutnya. Berdasarkan hasil evaluasi tahap akhir, 3 karya keroncong terbaik tersebut sebagai berikut:

1. Subaya Cinta (format Choir), Mp3 https://drive.google.com/file/d/1xd4SKdYXxxG NvqpxRNPxsP0Pi3MuraHF/view?usp=sharing

2. Sangkuriang, Mp3 https://drive.google.com/file/d/1DlQfiGs Emo23gD1UI1fM3ISa_wuSOM08/view? usp=sharing 
3. Sono, Video

https://drive.google.com/file/d/1Fg_WUe EYtBIvhMaHkr9SYODTSF008IRu/view? usp=sharing

Pemilihan ke tiga kelompok ini ditetapkan berdasarkan: (1) hasil evaluasi bersama mahasiswa, (2) pertimbangan unsur musik, dan (3) kesesuaian dengan tema besar, yaitu ide dasar penciptaan dari musik tradisi Sunda.

Dalam konteks pembahasan, peneliti memilih 2 lagu karena ke-2 lagu tersebut merepresentasikan unsur musik Sunda yang terkandung dalam musik keroncong hasil konstruksi ide dan gagasan mahasiswa, yakni lagu yang berjudul 'Sono' dan lagu 'Subaya Cinta'. Pertama lagu 'sono', Lagu ini disajikan dengan alat musik format keroncong, format tersebut terdiri dari bas, gitar, suling (alat melodi) serta cuk dan cak, kemudian 1 penyanyi disertai oleh 2 orang yang berperan sebagai backing vocal (penyanyi latar). Tampilan tersebut seperti gambar 1.

Gambar tersebut memperlihatkan format alat musik yang digunakan dalam lagu Sono, format tersebut sebetulnya sudah cukup mewakili format alat musik keroncong standar yakni terdiri dari cello, bas, gitar, cuk, cak dan flute (suling) atau biolin. Walaupun kelompok ini tidak menggunakan cello namun unsur penting dalam alat music keroncong cuk dan cak sudah cukup menjadi sarat utama dalam permaianan alat musik keroncong. Sebab kedua alat ini, yakni cuk dan cak merupakan alat musik utama dalam keroncong, di mana kedua alat ini merupakan sumber dari nama keroncong itu sendiri (Supiarza, Setiawan, \& Sobarna, 2019).

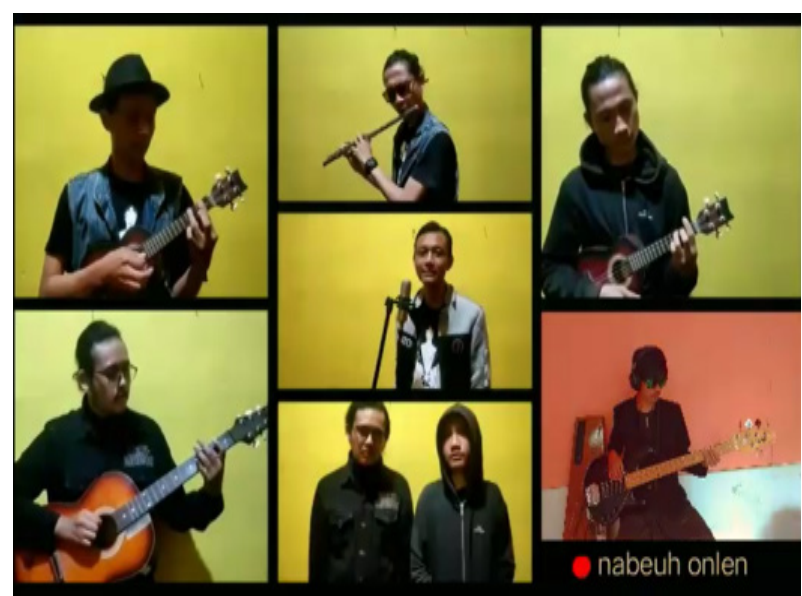

Gambar 1: Video virtual.

\section{Adopsi Permainan Alat Musik Terhadap Musik} Tradisi Sunda

Walaupun kelompok ini tidak menggunakan alat musik cello, namun pola permainan bas dimainkan dalam format cello yang berperan sebagai gong dan kendangan. Jadi pada pola permainan bas terdapat dua pola permainan, yakni sebagai kendangan dan gong.

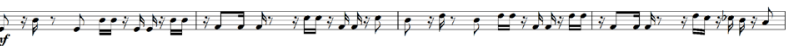

Notasi 1: Pola permainan bas mengadopsi permainan ritmik cello.

Pada notasi 1, terlihat pola permainan bas merangkap pola yang biasa dimainkan oleh cello keroncong sebagai kendangan, pola tersebut biasanya selalu mengambil ketukan di atas setelah bunyi bas yang berperan sebagai gong di ketukan pertama (tesis). Secara normal jika ada cello, maka bentuk permainan bass seperti gambar 3 .

Bass $\frac{2 i=100}{4}$

Notasi 2: Permainan bas secara normal.

Bas dalam permainan keroncong berperan sebagai goong yakni memberi penegasan di ketukan pertama dan umumnya bernilai dua ketukan. Namun dalam kasus kelompok ini, permainan bas dilakukan menjadi lebih padat, yakni berperan sebagai kendangan (memainkan pola cello) dan juga memainkan pola bas itu sendiri yang berperan sebagai goong (fondasi). Hal ini disebabkan dalam kelompok tidak terdapat orang lain yang bermain cello sehingga mau tidak mau bas harus memainkan dua pola. Hal ini dimungkinkan, tetapi menurut peneliti tetap kurang tepat, sebab terdapat perbedaan warna suara dalam kedua instrument itu, dan warna suara ini merupakan salah satu unsur penting yang menjadi karakteristik tersendiri dalam musik keroncong. Selain itu, cello juga merupakan satu khasanah keroncong sebagai budaya hybrid yakni terdapat modifikasi yang terjadi hasil kreativitas masyarakat Indonesia masa lalu yang menjadikan cello sebagai alat musik Barat dimainkan dengan digesek kemudian dipindah alihkan memiliki peran sebagai kendangan dengan memodifikasinya menjadi 3 senar, perbedaan tuning dan cara memainkannya di petik bahkan dipukul 
(Mintargo, 2017), (Wuryanto, R, L. Rohidi, R, T. Tarwiyah, 2016), (Rachman \& Utomo, 2017).

Sebagai adopsi dari gaya Sunda, ada yang menarik dari bentuk permainan alat musik bas pada kelompok ini, yaitu pola-pola irama pop Sunda dimainkan pada bagian-bagian tertentu, semisal seperti gambar 4 .

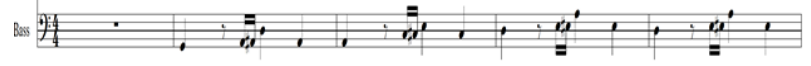

Notasi 3: Adopsi gaya bas pop Sunda.

Pola adopsi bas terhadap gaya lagu pop Sunda sangat jelas terlihat pada partitur di atas, yang menurut peneliti mahasiswa secara spontan terbawa dalam pola irama tersebut karena kebiasaan mendengar lagu irama pop Sunda yang telah terstandarisasi. Selain itu, pada saat pertemuan pertama untuk menentukan tema unsur tradisi Sunda mahasiswa dalam hal ini pemain bas sudah memiliki bayangan pola irama yang dia mainkan. Hal ini menurut peneliti sebagai suatu yang wajar, karena melodi utama dalam hal ini penyanyi memberikan rasa dan citra yang identik dengan apa yang selama ini dialami oleh pemain bas itu sendiri.

Untuk pola permainan cuk dan cak pada lagu ini terdapat pola permainan 'call and respond' lazimnya gaya Soloan, terdapat dua pola yakni dobel dan engkel. Pola ini dalam istilah tradisi gamelan Jawa disebut 'carukan' atau 'trulungan' sementara dalam tradisi gamelan Sunda istilah ini lebih kepada pemadatan irama yang sering disebut 'wiletan'. Pola permainan ini dapat dilihat pada notasi 4.

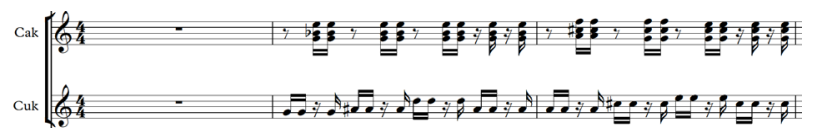

Notasi 4: Pola permainan cuk dan cak.

Pola permainan cuk dan cak dalam lagu ini merupakan adopsi gaya trulungan pada pola permainan gaya Solo. Sebetulnya pola ini adalah adopsi dari tradisi gamelan Jawa, dan jika dihubungan dengan pola permainan pada gamelan Sunda sangat identik dengan dialog antara alat music saron, yakni antara saron 1 dan saron 2 di mana dalam permainan gamelan Sunda kedua alat music ini saling bersautan, saron 1 lebih ke tesis dan saron 2 lebih ke arsis, sifat kedua alat tersebut 'call and respond'. Sehingga pola ini dalam pengamatan peneliti sangat identik dengan pola permainan adopsi dari gamelan Jawa dan Sunda hanya saja orang-orang Solo lebih dahulu menemukan dan mempakemkan gaya 'trulungan' menjadi khas daerah mereka. Mengenai alat musik yang mencoba untuk mengadopsi tradisi Sunda sangat menonjol pada permainan Bas, Cuk, Cak pada lagu ini.

\section{Unsur Tradisi Sunda pada Melodi Vokal Lagu Subaya Cinta}

Untuk hasil analisis musikologi tentang pendekatan tradisi Sunda dalam konteks melodi dan gaya bernyanyi, peneliti memilih 1 lagu, yaitu lagu 'Subaya Cinta'. Lagu Subaya Cinta, lagu ini menariknya dari sisi pengolahan vokal, yakni bersifat koor atau vokal grup yang dalam istilah musik tradisi Sunda berkaitan dengan istilah layeutan suara. Sebelum membahas mengenai unsur musik Sunda yang terkandung dalam komposisi musik Subaya Cinta, kiranya peneliti perlu membahas teks lagu terlebih dahulu. Berikut teks lagu Subaya Cinta:

\section{SUBAYA CINTA}

Timimiti babarengan

Sempal Guyon gogonjakan

Nyacapkeun kasono

Anjeun salawasna aya

Anjeun anu sok someah

Tetempoan tara salah

Pamadegan anu pancen

Ngijing sila bengkok sinembah

Sanajan abdi uninga, anjeun bakal miang

Lamun bisa tetep ngareng genak

Tong gampil mutuskeun

Sanajan taya tangan pangawasa

Anjeun anus ok someah

Tetempoan tara salah

Pamadegan anu pancen

Ngijing sila bengkok sinembah

Sanajan abdi uninga

Anjeun bakal miang, lamun bisa mah tetep

Ngareng genak, tong gampil mustuskeun

Sanajan taya tangan pangawasa

Timimiti barengan

Sempal guyon gogonjakan

Nyacapkeun kasono, anjeun salawasna aya

Lagu ini dimulai dengan koor sebagai pengantar sebanyak 4 birama setelah 4 birama 
sebelumnya diisi oleh intro yang dimainkan oleh alat musik flute, 4 birama intro vokal dengan bentuk 2 suara seperti notasi 5 .

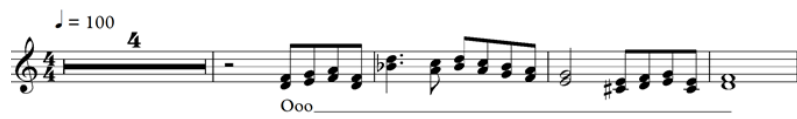

Notasi 5: Melodi vokal 2 suara.

Secara bentuk kalimat, 4 birama yang digunakan sebagai intro vokal dengan teks konsonan dimaksudkan sebagai jawaban dari 4 birama sebelumnya yang dimainkan oleh alat musik flute. Mungkin mahasiswa yang menciptakan komposisi ini tidak menyadari bahwa bagian awal ini kemudian membentuk gaya lagu ini bersifat tanya jawab. Menurut peneliti, pencipta lagu ini dipengaruhi oleh bentuk musik keroncong yang sangat terasa call and respon terutama pada permainan cuk dan cak, sehingga secara psikologis hal tersebut membentuk pola dalam pikiran mahasiswa. Pola pikiran itu dapat kita lihat pada perjalanan melodi selanjutnya.

to

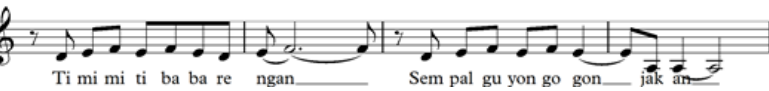

Notasi 6: Pola tanya jawab pada motif melodi lagu.

Notasi pada notasi 6 membuktikan bagaimana motif awal mempengaruhi pola Tanya jawab selanjutnya. Birama 9 dimulai dengan nada D kemudian pada birama 10 diakhiri naik ke nada $F$, kemudian birama 11 sampai 12 nadanya sama namun nada akhir diturunkan ke nada E. Selanjutnya lagu ini memiliki pola yang sama sampai bagian refrain. Bagian ini terdapat sampai birama 24, kemudian berubah pada bagian refrain dengan mencoba untuk menggunakan tangga nada minor natural yang bertujuan untuk memberikan kesan puncak dan lagu ini dalam bentuk refrain, notasi dapat dilihat pada notasi 7 .

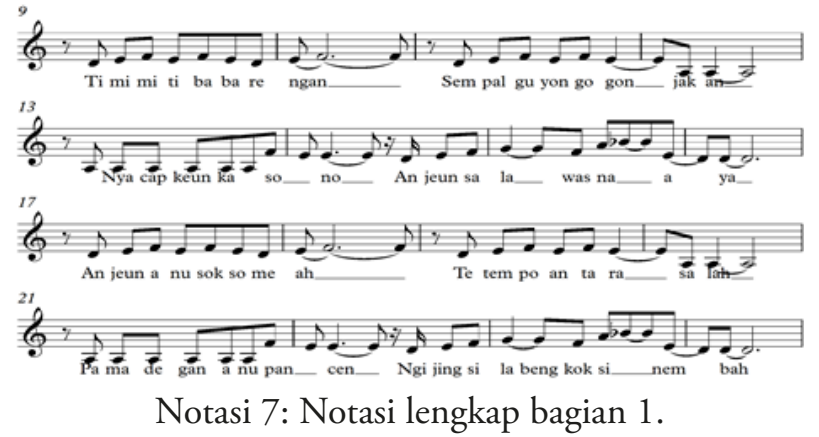

Notasi 7 menjadi bukti bahwa mahasiswa telah berhasil mendekatkan pola musik tradisi Sunda yakni dengan berupaya menggunakan notasi tangga nada madenda, yaitu urutan nada D-E-F$\mathrm{A}-\mathrm{Bb}$ sebagai urutan 5 nada pokok dalam tangga nada Sunda. Nada ini menjadi nada utama pada lagu ini, meskipun ada nada-nada di luar urutan ini seperti terdapatnya nada $G$, namun kemudian nada di luar urutan ini kemudian menjadi tidak berarti karena bersifat not lintas semata. Mengenai adanya not lintas dalam musik tradisi Sunda merupakan hal yang wajar. Dalam karawitan Sunda, bisa terjadi satu lagu yang disajikan memiliki multi-laras, artinya terdiri dari laras campuran dari berbagai laras yang ada dalam karawitan Sunda (Saepudin, 2017).

Dalam gaya vokal Sunda, terdapat ornamentasi yang sangat perlu diperhatikan, istilah ornamentasi dalam musik tradisi Sunda disebut dongkari. Ada jenis vokal dalam musik tradisi Sunda, yaitu: tembang Cianjuran, tembang Cigawiran, kawih kapasindenan dan kawih Wanda anyar. Masingmasing jenis tersebut terdapat berbagai macam dongkari/ornamentasi, ornamen diartikan sebagai hiasan lagu, atau lebih tepatnya lagi, hiasan melodi lagu. Dalam karawitan Sunda, selain istilah ornamen dikenal pula istilah senggol atau dongkari dalam tembang Sunda Cianjuran, yaitu motif hiasan lagu. Ornamen pada dasarnya merupakan komposisi yang terdiri dari gabungan motif-motif hiasan lagu (Hermawan, 2014). Berdasarkan keterangan mengenai aturan-aturan vokal dalam tradisi Sunda, penelitian ini bukan bertujuan untuk menggiring mahasiswa menjadi ahli dalam suatu konsep musik secara khusus, namun peneliti ingin mencoba suatu inovasi tentang penambahan repertoar musik keroncong dengan menstimulus ide dan gagasan mahasiswa untuk mencari dengan bebas dan mempraktikannya dalam berkreatifitas. Unsur tradisi Sunda sebagai wahana mahasiswa melakukan kreativitas atas ide dan gagasannya tersebut.

Dalam konteks tujuan penelitian ini, peneliti merasa telah berhasil untuk menciptakan inovasi pembelajaran kolaborasi dengan memerdekaan ide dan gagasan mahasiswa untuk menciptakan sesuatu. Sebagai penelitian awal, hasil penelitian ini telah 
berhasil membuat produk kreativitas mahasiswa secara kolaboratif, dan esensi penelitian ini secara garis besar telah berhasil, walaupun perlu adanya penyempurnaan pada produk yang dihasilkan. Maksud dari penyempurnaan tersebut adalah dilakukannya penelitian lanjutan untuk lebih dalam melakukan observasi dan analisis musik tradisi Sunda, kemudian hasilnya diharapkan dapat menciptakan produk rekaman lagu dari ciptaan mahasiswa melalui proses mixing dan editing secara professional. Oleh karena itu penelitian ini perlu ada kelanjutan untuk mencapai hasil yang sempurna.

\section{Kesimpulan}

Musik keroncong sebagai jenis musik hybrid seharusnya dapat direkonstruksikan dimana ruang dan waktu itu berada. Setiap era menciptakan generasi baru, yang memiliki ide dan gagasan baru dalam memperlakukan musik keroncong. Dengan memberikan kesempatan kepada generasi muda, dalam hal ini mahasiswa, maka musik keroncong akan terus tumbuh dan berkembang sesuai dengan kondisi dan situasi lingkungan generasi tersebut. Konstruksi musik keroncong masa lalu tidak akan pernah punah, akan selalu menjadi pegangan sebagai artefak estetis. Dengan berbagai strategi pembelajaran, dan metode pengembangan di dunia akademis, musik keroncong sebagai khasanah kebudayaan Indonesia akan selalu dapat bersaing terhadap kemajuan teknologi dan ilmu pengetahuan. Era disrupsi adalah keniscayaan yang terjadi pada masa kini, untuk dapat menyesuaikan diri salah satu cara adalah memberikan ruang pada mahasiswa sebagai representasi dunia ilmu pengetahuan untuk kreatif dan berkreasi dengan ikut serta mengembangkan dan melestarikan musik keroncong.

Penelitian ini membuktikan bahwa kalangan mahasiswa sebagai generasi muda, dapat secara sungguh-sungguh menuangkan ide dan gagasan musikal, turut serta mengembangkan musik keroncong berdasarkan musik tradisi Sunda. Persoalan kualitas hasil musik yang mereka kerjakan dapat didiskusikan diruang yang lain, akan tetapi setidaknya proyek ini adalah bukti sebuah partisipasi akademisi dalam pengembangan dan pelestarian musik keroncong.

\section{Kepustakaan}

Barendregt, Bart. Bogaerts, E. (2016). Merenungkan gema, Perjumpaan Musikal Indonesia-Belanda. Jakarta: Yayasan Obor Indonesia dan KITLV. Elliott, J. D. (1995). Music Matters: A New Philosophy of Music Education. Newyork: Oxford University Press.

Ganap, V. (2000). Tugu Keroncong Music: Hybrid Genre of Portuguese Sojourn. Jurnal Pengetahuan Dan Penciptaan Seni Seni, 2(4), 213-228.

Ganap, V. (2006). Pengaruh Portugis pada Musik Keroncong. Harmonia, 02(4), 1-14.

Gerlach, J. M. (1994). Is this Collaboration? New Directions for Teaching and Learning, 5(14). https://doi.org/10.1002/tl.37219945903

Hardjana, S. (2003). Corat-coret Musik Kontemporer Dulu dan Kini. Jakarta: Kerjasama Ford Foundation dan Masyarakat Seni Pertunjukan Indonesia.

Harmunah. (1996). Musik Keroncong Sejarah, Gaya dan Perkembangan. Yogyakarta: Pusat Musik Liturgi.

Hasan. (2009). Action Research: Desain Penelitian Integratif untuk Mengatasi Permasalahan Masyarakat. AKSES: Jurnal Ekonomi Dan Bisnis, 4(8), 177-188. https://doi. org/10.31942/akses.v4i8.523

Hermawan, D. (2014). Fenomena Gender dalam Dongkari. Panggung, 24 No.1(212), 25-38.

Joan, L. (1989). Pianis Remaja, Buku Pegangan untuk Guru dan Murid. Jakarta: PT. Gramedia Pustaka Utama.

Latifah, K. (1983). Istilah-Istilah Musik. Jakarta: Djambatan.

Lisbijanto, H. (2013). Musik Keroncong. Jakarta: Graha Ilmu.

Margaret J. Kartomi, David Goldsworthy, Catherine Falk, B. K. (1978). Studies in Indonesian music. Centre of Southeast Asian Studies, Monash UniversityMonash University.

Mintargo, W. (2017). Akulturasi Budaya dalam Musik Keroncong di Indonesia. Nuansa 
Journal of Arts and Design, 1(1), 10-22.

O'Brien, R. (1998). An Overview of the Methodological Approach of Action Research. Faculty of Information Studies. USA: University of Toronto.

Panitz, T. (1997). Collaborative versus Cooperative Learning: A Comparison of the Two Concepts Which Will Help Us Understand the Underlying Nature of Interactive Learning. Cooperative Learning and College Teaching, 8(2), 13. https://doi.org/Akses 17 Januari 2015

Rachman, A., \& Utomo, U. (2017). "Sing Penting Keroncong" Sebuah Inovasi Pertunjukkan Musik Keroncong di Semarang. Jurnal Pendidikan dan Kajian Seni, 3(1). https:// doi.org/10.30870/jpks.v3i1.4066

Rohidi, T. R. (2011). Metodologi Penelitian Seni. Semarang: Cipta Prima Nusantara.

Saepudin, A. (2017). Laras, Surupan, dan Patet dalam Praktik Menabuh Gamelan Salendro Alamat Laras, Surupan, dan Patet dalam Praktik Menabuh Gamelan Salendro. Resital, 16(1), 52-64.

Suadi, H. (2017). Djiwa Manis Indoeng Disajang, Musik Dan Dunia Hiburan Tempo Dulu. Bandung: PT. Kiblat Buku Utama.

Suharto, M. (1982). Membina Paduan Suara dan Grup Vokal. Jakarta: PT. Gramedia Pustaka Utama.

Supiarza, H. (2019). Rekonstruksi Musik Keroncong Anak Muda di Kota Bandung (Universitas Padjadjaran). Retrieved from http:// repository.unpad.ac.id/frontdoor/index/ index/docId/24652

Supiarza, H., \& Sarbeni, I. (2021). Teaching and
Learning Music in Digital Era: Creating Keroncong Music for Gen Z Students Through Interpreting Poetry. Harmonia: Journal of Arts Research and Education, 21(1), 123-139.

Supiarza, H., Setiawan, D., \& Sobarna, C. (2019). Pola Permainan Alat Musik Keroncong dan Tenor di Orkes Keroncong Irama Jakarta. Resital: Jurnal Seni Pertunjukan, 20(2), 108-120. https://doi.org/10.24821/resital. v20i2.2459

Suryani, N. (2010). Implementasi Model Pembelajaran Kolaboratif untuk Meningkatkan Ketrampilan Sosial Siswa. Majalah Ilmiah Pembelajaran, 8(2).

Suryati, Widodo, W, T. (2020). Sight Singing sebagai Strategi Pembelajaran Instrumen Piano di Prodi Pendidikan Musik ISI Yogyakarta. Resital: Jurnal Seni Pertunjukan, 21(2), 99-112.

Tinzmann, M. B., Jones, B. F., Fennimore, T. F., Bakker, J., Fine, C., \& Pierce, J. (1990). What Is the Collaborative Classroom? Ncrel, (January), 1-26. Retrieved from http:// methodenpool.uni-koeln.de/koopunterricht/ The Collaborative Classroom.htm

Wuryanto, R, L. Rohidi, R, T. Tarwiyah, T. (2016). Yen Ing Tawang Ana Lintang: Kasus Bentuk Musik Keroncong Group Congrock 17 di Semarang Lucky. Catharsis : Journal of Arts Education, 5(2), 79-83.

Yampolsky, P. B. (2013). Music and media in the Dutch East Indies: Gramophone records and radio in the late colonial era, 1903--1942. Retrieved from http://search.proquest.com/ docview/1428745765? accountid=13771 